\title{
Hydrochemical evaluation of the quality of some Brazilian waters
}

\author{
D. M. Bonotto, L. Caprioglio, H. K. Itoman, M. Santilli \\ \& B. W. Tessari \\ Departamento de Petrologia e Metalogenia, \\ Instituto de Geociências e Ciências Exatas-UNESP, Rio Claro, Brazil
}

\begin{abstract}
This investigation was carried out within the Paraná sedimentary basin and neighbourhood in Brazil and involved the sampling of different water types with the purpose of evaluating its quality. Several methods were utilized for acquiring the hydrochemical data and a novel technique has been developed for evaluating the gross alpha and beta radioactivities in water, through a combined gamma-alpha spectrometry technique. The results obtained for the analyzed samples were compared with the guideline values established by the São Paulo State and Brazilian Health Ministry legislations for defining potable water standards and for the prevention and control of pollution in the environment. The hydrochemical data allowed evaluation of diverse problems related to the interaction between society and the environment such as sugarcane production and the releases associated with gas stations suppliers. The geogenic input of sulfate in groundwater was also identified. The established radiometric technique was properly calibrated and successfully applied to the analysis of different water types utilized for human consumption.

Keywords: drinking water quality, groundwater, hydrochemistry, vinasse, sugar and alcohol production, gross alpha radioactivity, gross beta radioactivity.
\end{abstract}

\section{Introduction}

For many years, environmentalists, humanitarians, government agencies, politicians, educators, and others have expressed concern for protecting hydrological resources against pollutants. In Brazil, waste disposal areas related to the production and processing of sugarcane may also be a source of contaminants to the hydrologic environment. During 2007, sugarcane production 
in the central, southeastern and southern Brazilian regions reached 375 million tons, the processing of which yielded 17.2 billion liters of alcohol and 23.7 million tons of sugar [1]. The disposal of vinasse, the major effluent from the ethanol industry, has represented a major environmental problem in these areas, thus, it has been utilized as an alternative to supply several nutrients in crop production such as those reported by various research works documenting an increase in sugarcane productivity [2,3]. However, the problem occurs when some soils do not respond positively to the application of this acid material, whose high BOD-Biological Oxygen Demand can cause damage to aquatic life, especially when dumped in large volumes $[4,5]$.

The number of gas station suppliers in São Paulo State corresponds to 7500, which is significant if compared with $\sim 28500$ existing in Brazil. They must provide fuel to about 15 million vehicles in São Paulo State, but this number is increasing, for instance, it rose $26 \%$ from 2002 to 2006 [6]. Therefore, the releases associated with gas stations suppliers also constitute an important source of contaminants to the hydrologic environment.

Despite these diverse problems related to the interaction between society and the environment, the geogenic input of elements mainly in groundwater resources have constituted an additional question to be solved by authorities involved with the management of hydrological resources. This is because the introduction of constituents able to cause modification in the water quality for drinking purposes may occur. The potential health hazards from natural radionuclides is among the aspects that have been considered worldwide in consuming water, with many countries adopting the guideline activity concentration for drinking water quality. However, the measurements of radiological parameters in Brazilian potable waters are scarce because, in general, it warrants using more sophisticated and time-consuming procedures.

This paper describes the results of some hydrochemical monitoring held in different aquifer systems in order to evaluate the water quality. A new methodological approach for evaluating gross alpha and beta radioactivities in water, through a combined gamma-alpha spectrometry technique, is also described. This approach utilized non-expensive gamma ray spectrometry through a well-type $\mathrm{NaI}(\mathrm{Tl})$ scintillation detector and alpha spectrometry through surface barrier detectors, which allow direct identification of some radionuclides. The technique was properly calibrated and successfully applied to the analysis of different water types utilized for human consumption.

\section{Analytical methods}

Several standard analytical techniques were used for obtaining the parameters analyzed in the water samples, for example, dilution and incubation method, evaporation, methyl orange end-point titration, potentiometry, ion selective electrode, and spectrophotometry. Portable meters were used for in situ determinations of temperature, $\mathrm{pH}$ and dissolved oxygen (DO). The $\mathrm{pH}$ measurement was performed by a digital portable meter coupled to a combination glass electrode; buffer solutions equilibrated with the sample 
temperature were utilized to calibrate the equipment before the analyses. The DO was determined in a pointer meter recording the potential values generated by an $\mathrm{O}_{2}$ sensible electrode consisting of a metallic wire covered by a thin layer of gold.

The true color for two water samples was determined by colorimetry (wavelength $455 \mathrm{~nm}$ ) after filtering the suspended materials and using a program stored in the Hach DR/2000 spectrophotometer that was calibrated in color units based on the APHA-recommended standard of 1 color unit being equal to $1 \mathrm{mg}$ $\mathrm{L}^{-1}$ platinum as chloroplatinate ion [7]. The same samples were analyzed for total coliforms through the fast ColiQuik Presence/Absence test [7] that utilizes a medium providing specific indicator nutrients, i.e. ONPG (o-nitrophenyl- $\beta$-dgalactopyranoside) and MUG (4-methylumbelliferyl- $\beta$-d-glucuronide).

A bench digital meter provided electrical conductivity readings obtained though a $1 \mathrm{~cm}^{2}$ area platinum electrode calibrated with $\mathrm{KCl}$ standards. The dry residue (DR) ( total dissolved solids, TDS) content was evaluated on evaporating the filtrate to dryness in a weighed flask that was dried to constant weight at $180^{\circ} \mathrm{C}$, with the increase in flask weight representing DR [8]. The total alkalinity of the water samples was determined by titration using a titrator with sulfuric acid standard solution to an end point evidenced by the color change of a standard indicator solution [8]. The obtained values corresponded to the bicarbonate concentrations since neither carbonate nor hydroxide were characterized.

The BOD (Biochemical Oxygen Demand) was measured by the dilution method, employing high purity distilled water provided by Barnstead Mega-Pure One Liter Water Still. For this purpose, the dissolved oxygen (DO) content remaining in six portions of each well-mixed sample transferred to separated 300-mL glass-stoppered bottles was evaluated after a five-day incubation period; the DO values measured potentiometrically were plotted against the $\mathrm{mL}$ of sample taken, yielding a straight line that allowed obtain the BOD data. The chemical oxygen demand (COD) was evaluated by the dichromate reflux method [8], using aliquots acidified to $\mathrm{pH}=2$ with concentrated $\mathrm{H}_{2} \mathrm{SO}_{4}$. The organic matter (OM) was determined by the dichromate method that is based on the organic carbon oxidation to $\mathrm{CO}_{2}$ with a parallel reduction of $\mathrm{Cr}^{6+}$ to $\mathrm{Cr}^{3+}$ and an accompanying color change from orange to green whose intensity is measured at $610 \mathrm{~nm}$ [7]. The Hach DR/2000 spectrophotometer was calibrated for performing the fats, oil and grease (FOG) concentration readings at $410 \mathrm{~nm}$; the mineral oil for Edwards E2M8 vacuum pump was utilized for obtaining a reliable calibration curve.

Calcium hardness (as $\mathrm{CaCO}_{3}$ ) and magnesium hardness (as $\mathrm{MgCO}_{3}$ ) of the water samples were determined by the colorimetric method (wavelength $522 \mathrm{~nm}$ ) after chelating calcium with EGTA and calcium and magnesium with EDTA [7], parameters that allowed to evaluate $\mathrm{Ca}$ and $\mathrm{Mg}$ contents. The analyses of dissolved sodium were done by flame photometry, whereas potassium was determined by the tetraphenylborate method that is based on the combination of $\mathrm{K}$ with sodium tetraphenylborate to form an insoluble white solid read at $650 \mathrm{~nm}$ $[7]$. 
Chloride and fluoride were measured potentiometrically after adding a known amount of ionic strength adjustor to each sample, when necessary. Orion ionselective electrodes coupled into a digital meter were used, where standards containing variable concentrations of chloride and fluoride were utilized for preparing calibration curves consisting on logarithmic straight lines involving the potential and concentration readings. Nitrate, nitrite, ammonium, phosphate and sulfate were determined by colorimetry [7] after adding reagents to the samples that are able to produce colored complexes read by a program stored in Hach $\mathrm{DR} / 2000$ spectrophotometer previously calibrated in variable concentrations at different wavelengths.

The metals $\mathrm{Ba}, \mathrm{Cr}^{6+}$ and $\mathrm{Fe}$ were also measured colorimetrically. The amount of turbidity present in a fine white barium sulfate precipitate was read at $450 \mathrm{~nm}$ in order to supply the Ba concentration data. $\mathrm{Cr}^{6+}$ was determined on using 1,5diphenylcarbohydrazide, which reacts to give a purple color read at $540 \mathrm{~nm}$ when $\mathrm{Cr}^{6+}$ is present. The 1,10 phenanthroline indicator formed an orange color in proportion to the iron concentration, which was read at $510 \mathrm{~nm}$.

\section{Gross alpha and beta activity measurements}

The method developed for evaluating the gross alpha and beta radioactivities in water samples comprised a combined gamma-alpha spectrometry technique. The gamma rays spectrometry is a non-destructive method that has a lot of advantages from the technical point of view over beta spectrometry, inclusive allowing the identification and quantification of $\beta^{-}$-emitters radionuclides. The alpha spectrometry is based on the direct measurement of the alpha particles generated in the ${ }^{238} \mathrm{U}$ and ${ }^{232} \mathrm{Th}$ decay series.

The water samples $(1 \mathrm{~L})$ were evaporated at $80-90^{\circ} \mathrm{C}$ up to a final volume of $12 \mathrm{ml}$, and stored into a glass flask properly sized for insertion into a 2 " $\times 2$ " $\mathrm{NaI}(\mathrm{Tl})$ well-type scintillation detector for gamma spectrometry. The spectrometric system utilized a 2,048-channel multichannel analyzer provided by ORTEC ACE $2 \mathrm{~K}$ hardware controlled by MAESTRO software. The energy calibration of the system was performed using the radioactive sources ${ }^{137} \mathrm{Cs}(\gamma$ rays energy $=0.66 \mathrm{MeV})$ and ${ }^{60} \mathrm{Co}(\gamma$-rays energy $=1.17$ and $1.33 \mathrm{MeV})$, a solution containing ${ }^{133} \mathrm{Ba}$ ( $\gamma$-rays energy $=0.36$ and $\left.0.39 \mathrm{MeV}\right)$, and pure powdered $\mathrm{KCl}(52 \mathrm{wt} \%$ in $\mathrm{K})$ as a source of ${ }^{40} \mathrm{~K}(\gamma$-rays energy $=1.46 \mathrm{MeV})$. The energy calibration curve of the gamma spectrometer is reliable to identify the presence of the major $\beta^{-}$-emitting nuclides for ${ }^{232} \mathrm{Th}$ and ${ }^{238} \mathrm{U}$-descendants.

The gamma spectrometer was efficiency calibrated on using ${ }^{232} \mathrm{Th}$ descendants in NBL monazite sand standards having different Th concentrations and providing from New Brunswick Laboratory, USA. The critical level of detection $(L c)$ [9] was estimated in number of counts, count rate, and activity, and corresponded to 834 counts, $0.008 \mathrm{cps}$ and $0.03 \mathrm{~Bq}$, respectively.

Each final volume $(12 \mathrm{~mL})$ of the solution that had been subjected to gamma spectrometry through the 2 " $\times 2$ " $\mathrm{NaI}(\mathrm{Tl})$ well-type scintillation detector was evaporated at $100^{\circ} \mathrm{C}$ up to dryness into a 1 "-diameter aluminum disk. Then, an alpha spectrometric system based on surface barrier detectors was utilized for 
yielding the gross alpha data associated to the disks containing the dry residue. Four $0.1 \mathrm{~mm}$ depletion depth, $200 \mathrm{~mm}^{2}$ area surface barrier detectors were utilized for yielding alpha spectra in order to provide the gross alpha data. The $\alpha$ spectra were recorded on an EG\&G ORTEC 919 Spectrum Master Multichannel Buffer that provided four 1,024-channel analyzers controlled by MAESTRO

Table 1: $\quad$ Results of the analyses of groundwater samples collected from the monitoring wells drilled at Cacique gas station, Araçatuba municipality.

\begin{tabular}{cccccccccc}
\hline $\begin{array}{c}\text { Paramet } \\
\mathrm{er}\end{array}$ & Unit & GW1 & GW2 & GW3 & GW4 & GW5 & GW6 & GW7 & GW8 \\
\hline $\mathrm{pH}$ & - & 6.8 & 6.0 & 5.7 & 5.2 & 6.3 & 5.5 & 5.3 & 5.0 \\
$\sigma^{\mathrm{a}}$ & $\mu \mathrm{S} / \mathrm{cm}$ & 220 & 290 & 80 & 260 & 200 & 70 & 70 & 70 \\
$\mathrm{TDS}^{\mathrm{b}}$ & $\mathrm{mg} / \mathrm{L}$ & 110 & 115 & 60 & 140 & 105 & 60 & 65 & 68 \\
$\mathrm{HCO}_{3}{ }^{-}$ & $\mathrm{mg} / \mathrm{L}$ & 64 & 12 & 8 & 2 & 58 & 4 & 8 & 6 \\
$\mathrm{SO}_{4}{ }^{-}$ & $\mathrm{mg} / \mathrm{L}$ & $<1.0$ & $<1.0$ & $<1.0$ & $<1.0$ & $<1.0$ & $<1.0$ & $<1.0$ & $<1.0$ \\
$\mathrm{NO}_{3}{ }^{-}$ & $\mathrm{mg} / \mathrm{L}$ & $<0.4$ & 17.6 & 4.8 & 77.4 & $<0.4$ & 0.4 & $<0.4$ & 0.4 \\
$\mathrm{NO}_{2}^{-}$ & $\mathrm{mg} / \mathrm{L}$ & 0.02 & 0.013 & 0.013 & 0.02 & 0.013 & 0.016 & 0.01 & 0.016 \\
$\mathrm{NH}_{4}^{+}$ & $\mathrm{mg} / \mathrm{L}$ & 0.013 & 0.14 & 0.15 & 0.10 & 1.81 & 0.013 & 0.09 & 0.09 \\
$\mathrm{Cl}^{-}$ & $\mathrm{mg} / \mathrm{L}$ & 0.1 & 25.8 & 0.5 & 1.9 & 0.5 & 0.4 & 0.4 & 0.5 \\
$\mathrm{Ba}^{2+}$ & $\mathrm{mg} / \mathrm{L}$ & $<1.0$ & $<1.0$ & 1.0 & 1.0 & 1.0 & 1.0 & 1.0 & 1.0 \\
$\mathrm{Cr}^{6+}$ & $\mathrm{mg} / \mathrm{L}$ & 0.01 & $<0.01$ & $<0.01$ & $<0.01$ & $<0.01$ & $<0.01$ & $<0.01$ & $<0.01$ \\
$\mathrm{BOD}^{\mathrm{c}}$ & $\mathrm{mg} / \mathrm{L}$ & 4.0 & 4.5 & 4.0 & 4.0 & 4.6 & 4.0 & 4.7 & 4.1 \\
$\mathrm{FOG}^{\mathrm{d}}$ & $\mathrm{g} / \mathrm{L}$ & $<0.01$ & $<0.01$ & $<0.01$ & 1.3 & 0.1 & 0.1 & 0.2 & $<0.01$ \\
\hline $\mathrm{a} \sigma=\mathrm{Electrical} \mathrm{Conductivity}_{\sigma}\left(\mathrm{at} 25^{\circ} \mathrm{C}\right) ;{ }^{\mathrm{b}} \mathrm{TDS}=$ Total Dissolved Solids; & ${ }^{\mathrm{c}} \mathrm{BOD}=$
\end{tabular}

Biochemical Oxygen Demand; ${ }^{\mathrm{d}} \mathrm{FOG}=$ Fats, Oil and Grease.

Table 2: $\quad$ Results of the analyses of groundwater samples collected from the monitoring wells drilled at CIESA, Penápolis municipality.

\begin{tabular}{cccccccc}
\hline Parameter & Unit & GW1 & GW2 & GW3 & GW4 & GW5 & GW6 \\
\hline $\mathrm{pH}$ & - & 7.7 & 7.5 & 5.7 & 7.8 & 7.5 & 7.5 \\
$\sigma^{\mathrm{a}}$ & $\mu \mathrm{S} / \mathrm{cm}$ & 65 & 60 & 80 & 110 & 60 & 60 \\
$\mathrm{HCO}_{3}^{-}$ & $\mathrm{mg} / \mathrm{L}$ & 16 & 8 & 8 & 18 & 6 & 8 \\
$\mathrm{SO}_{4}^{2-}$ & $\mathrm{mg} / \mathrm{L}$ & $<1.0$ & $<1.0$ & $<1.0$ & $<1.0$ & $<1.0$ & $<1.0$ \\
$\mathrm{NO}_{3}{ }^{-}$ & $\mathrm{mg} / \mathrm{L}$ & 2.6 & 2.6 & 10.6 & 6.2 & 4.0 & 1.3 \\
$\mathrm{NO}_{2}^{-}$ & $\mathrm{mg} / \mathrm{L}$ & 0.016 & 0.016 & 0.016 & 0.013 & 0.016 & 0.013 \\
$\mathrm{NH}_{4}{ }^{-}$ & $\mathrm{mg} / \mathrm{L}$ & 0.27 & 0.21 & 0.22 & 0.46 & 0.21 & 0.21 \\
$\mathrm{Cl}^{-}$ & $\mathrm{mg} / \mathrm{L}$ & 0.16 & 0.21 & 0.15 & 0.15 & 0.13 & 0.16 \\
$\mathrm{Ba}^{2+}$ & $\mathrm{mg} / \mathrm{L}$ & 1.0 & 1.0 & 1.0 & 1.0 & 1.0 & 1.0 \\
$\mathrm{Cr}^{6+}$ & $\mathrm{mg} / \mathrm{L}$ & $<0.01$ & $<0.01$ & $<0.01$ & $<0.01$ & 0.01 & $<0.01$ \\
$\mathrm{COD}^{\mathrm{b}}$ & $\mathrm{mg} / \mathrm{L}$ & 11.1 & 10.5 & 10.3 & 7.8 & 7.6 & 8.0 \\
$\mathrm{BOD}^{\mathrm{c}}$ & $\mathrm{mg} / \mathrm{L}$ & 4.8 & 4.7 & 4.5 & 3.9 & 3.8 & 4.0 \\
$\mathrm{FOG}^{\mathrm{d}}$ & $\mathrm{g} / \mathrm{L}$ & 3.1 & $<0.01$ & $<0.01$ & 0.05 & $<0.01$ & $<0.01$ \\
\hline
\end{tabular}

${ }^{\mathrm{a}} \sigma=$ Electrical Conductivity $\left(\right.$ at $\left.25^{\circ} \mathrm{C}\right) ;{ }^{\mathrm{b}} \mathrm{COD}=$ Chemical Oxygen Demand; ${ }^{\mathrm{c}} \mathrm{BOD}=$ Biochemical Oxygen Demand; ${ }^{\mathrm{d}} \mathrm{FOG}=$ Fats, Oil and Grease. 


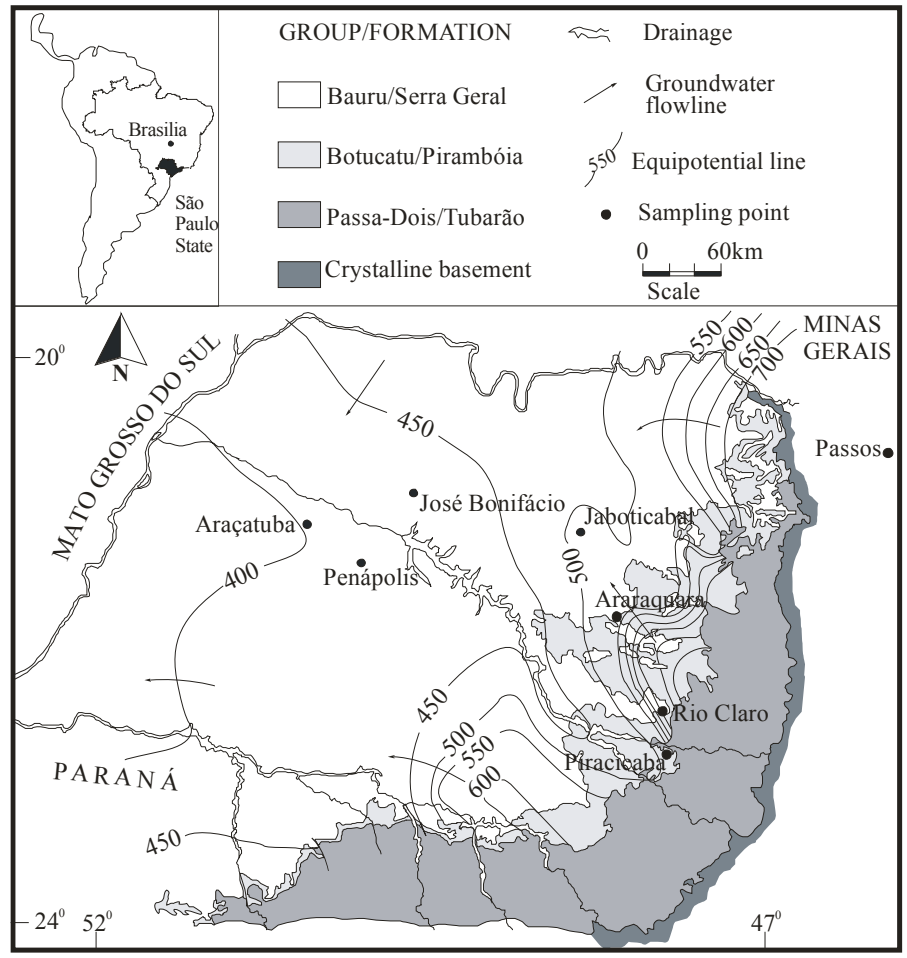

Figure 1: A simplified geological map of São Paulo State and the general groundwater flow in the Guarani aquifer according to [11].

software. The energy calibration of the system was performed using a radioactive source prepared at the Centre de Faibles Radioactivités, CNRS-CEA, France, and containing $0.91 \mathrm{~Bq}$ of ${ }^{238} \mathrm{U}$. In addition, the same source included ${ }^{234} \mathrm{U}(\alpha-$ particles energy $=4.77 \mathrm{MeV}$ ) and $0.17 \mathrm{~Bq}$ of ${ }^{232} \mathrm{U}$, that is an artificial uranium isotope produced in nuclear reactor by neutron activation of ${ }^{232} \mathrm{Th}$, has a half-life of 72 years, and originates ${ }^{228} \mathrm{Th}$ by the emission of $\alpha$-particles of $5.3 \mathrm{MeV}$ energy [10]. The ${ }^{228} \mathrm{Th}$-daughters correspond to those occurring in the ${ }^{232} \mathrm{Th}$ decay series.

The alpha spectrometer was calibrated for performing activity concentration readings on using a known amount $(0.28 \mathrm{~Bq})$ of ${ }^{232} \mathrm{U}$ that was added to $\mathrm{KCl}$ solutions of variable concentration (between 1 and $1000 \mathrm{mg} / \mathrm{L}$ ) and conductivity (between 22 and $2100 \mu \mathrm{S} / \mathrm{cm}$ ). The alpha spectrometric system provided readings within the energy range of 3-8 $\mathrm{MeV}$ that is reliable to identify the presence of the major $\alpha$-emitting nuclides for ${ }^{232} \mathrm{Th}$ and ${ }^{238} \mathrm{U}$-descendants. The critical level of detection $(L c)$ [9] was estimated in activity, and ranged from 0.0005 up to $0.003 \mathrm{~Bq}$ (average $=0.001 \mathrm{~Bq}$ ). 


\section{The selected sites in São Paulo and Minas Gerais States}

The methods described in items 2 and 3 were applied to areas situated at São Paulo and Minas Gerais States in Brazil that exhibit great differences in lithology and wastes released into the environment. They are located at the following municipalities and nearby: Araraquara, Jaboticabal, José Bonifácio, Penápolis, Araçatuba, and Passos (Fig. 1).

The area studied in São Paulo State is geologically situated at the Paraná sedimentary basin. The sedimentary sequence is almost undisturbed, with gentle dips towards the center of the basin, and covers since the Silurian-Devonian up to the Cretaceous periods. The major rock types [12] include sandstones, conglomerates, diamictites, siltstones, shales, mudstones, limestones, basalts and diabases that belong to Tubarão Group (Itararé Subgroup and Tatuí Formation), Passa Dois Group (Irati and Corumbataí Formations), São Bento Group (Pirambóia, Botucatu, and Serra Geral Formations), Bauru Group and different types of Cenozoic covers (Fig. 1).

The area studied in Minas Gerais State is situated at the southern portion of the Brasília belt is characterized by foreland thin-skinned thrusting and folding, with eastward directed tectonic transport of at least $150 \mathrm{~km}$ onto the southwestern border of the São Francisco craton, during the Brasiliano orogeny [13]. Three main tectonic units are separated by major thrusts and display contrasting lithological, structural, geochronological and metamorphic characteristics, being one represented by the Passos nappe where metamorphism and deformation are more intense. The Proterozoic mafic rocks like amphibolites and chlorite schists are among the major types occurring in the area [13].

Tietê River is the major drainage system at São Paulo State, which originates close to São Paulo city, cross the whole state, and discharges into Paraná River at the border with Mato do Grosso Sul State. Multiaquifer systems mainly comprising sandstones and basalts plus sediments from Passa Dois Group behaving as aquitards have been proposed to represent the hydrostratigraphy of the Paraná basin [14]. Groundwater occurs within the interflow zones and along cooling joints in basalts and diabases from Serra Geral Formation. The sandstones of Cretaceous age (Bauru Group) are moderately cemented and exhibit adequate properties to storage water. The Paleozoic sediments (Devonian-Permian age) also provide water that is relatively mineralized in the central parts of the basin and contains $\mathrm{H}_{2} \mathrm{~S}$ in some wells. The Guarani aquifer corresponds to sediments (Triassic-Jurassic age) consisting of silty and shaly sandstones of fluvial-lacustrine origin (Pirambóia Formation) and variegated quartzitic sandstones accumulated by eolian processes under desert conditions (Botucatu Formation). It has continental dimensions [14], extends over some $950,000 \mathrm{~km}^{2}$ within the Paraná sedimentary basin, has an average thickness of 300-400 m, overlies formations ranging from the igneous basement to Paleozoic sediments of the Passa Dois and Tubarão Groups, and is covered by a thick (up to $1,500 \mathrm{~m}$ ) basaltic package of Serra Geral Formation and Cretaceous sediments of the Bauru Group (Fig. 1). 
Table 3: Results of the analyses of groundwater samples collected from the monitoring wells drilled at Borracharia Paulista, José Bonifácio municipality.

\begin{tabular}{cccccccc}
\hline Parameter & Unit & GW1 & GW2 & GW3 & GW4 & GW5 & GW6 \\
\hline $\mathrm{pH}$ & - & 4.8 & 4.2 & 4.6 & 4.6 & 4.2 & 4.5 \\
$\sigma^{\mathrm{a}}$ & $\mu \mathrm{S} / \mathrm{cm}$ & 600 & 800 & 700 & 700 & 600 & 600 \\
$\mathrm{TDS}^{\mathrm{b}}$ & $\mathrm{mg} / \mathrm{L}$ & 280 & 370 & 340 & 330 & 300 & 280 \\
$\mathrm{~K}^{+}$ & $\mathrm{mg} / \mathrm{L}$ & 8.3 & 18.0 & 18.0 & 19.7 & 4.2 & 1.8 \\
$\mathrm{Ca}^{2+}$ & $\mathrm{mg} / \mathrm{L}$ & 0.16 & $<0.01$ & $<0.01$ & $<0.01$ & 0.02 & 0.63 \\
$\mathrm{Mg}^{2+}$ & $\mathrm{mg} / \mathrm{L}$ & 0.69 & 0.24 & 0.51 & 0.75 & 0.81 & 0.18 \\
$\mathrm{SO}_{4}{ }^{2-}$ & $\mathrm{mg} / \mathrm{L}$ & 5.0 & 2.0 & 1.0 & 1.0 & 1.0 & 1.0 \\
$\mathrm{NO}_{3}{ }^{-}$ & $\mathrm{mg} / \mathrm{L}$ & 22.0 & 91.5 & 65.1 & 44.0 & 22.9 & 0.44 \\
$\mathrm{NO}_{2}{ }^{-}$ & $\mathrm{mg} / \mathrm{L}$ & 0.016 & 0.016 & 0.02 & 0.016 & 0.016 & 0.016 \\
$\mathrm{NH}_{4}{ }^{+}$ & $\mathrm{mg} / \mathrm{L}$ & 0.52 & 0.77 & 0.38 & 0.09 & $<0.01$ & 0.37 \\
$\mathrm{PO}_{4}{ }^{3-}$ & $\mathrm{mg} / \mathrm{L}$ & 0.03 & 0.02 & 0.06 & 0.02 & 0.01 & 0.01 \\
$\mathrm{OM}^{\mathrm{c}}$ & $\mathrm{mg} / \mathrm{L}$ & $<1.0$ & $<1.0$ & $<1.0$ & $<1.0$ & $<1.0$ & $<1.0$ \\
$\mathrm{BOD}^{\mathrm{d}}$ & $\mathrm{mg} / \mathrm{L}$ & 0.8 & 0.9 & 1.0 & 0.5 & 0.6 & 3.0 \\
\hline
\end{tabular}

${ }^{\mathrm{a}} \sigma=$ Electrical Conductivity $\left(\right.$ at $\left.25^{\circ} \mathrm{C}\right) ;{ }^{\mathrm{b}} \mathrm{TDS}=$ Total Dissolved Solids; ${ }^{\mathrm{c}} \mathrm{OM}=$ Organic Matter; ${ }^{\mathrm{d}} \mathrm{BOD}=$ Biochemical Oxygen Demand.

Fault patterns are an important control on the drainage system at the Passos area in Minas Gerais State. Grande River running over the Proterozoic mafic rocks is the major drainage system in the region, which also reaches Paraná River after joining with Paranaíba River. Despite the occurrence of superficial granular aquifers in the area, the drilling companies have mainly exploited aquifers in fractured rocks due to the better yielding of the wells. The occurrence of falls is frequent due to the altitude and relief, as well springs that discharge along joints, cracks, and faults.

The sampling for chemical analysis was performed for groundwater samples collected at monitoring wells installed around a gas station supplier (GW1 to GW8 at Araçatuba) and in fields irrigated with vinasse for sugarcane crop (GW1 to GW6 at Penápolis, GW1 to GW6 at José Bonifácio, and GW1 to GW4 at Piracicaba). Groundwater samples providing from one tubular well (GW at Rio Claro) and two springs (SP1 at Piracicaba and SP2 at Passos) were also collected and analyzed, as they have been utilized for human consumption. In order to facilitate the comparison of the results at Passos, another surface water sample (SW) from a small fall was collected and analyzed too.

The analysis for gross alpha and beta activity concentration was performed for groundwater and surface water samples that are distributed for human consumption. They were collected at residential areas occurring in urban and rural zones, industries, and water supply systems located at Araraquara/ Jaboticabal municipalities and nearby (Fig. 1). 
Table 4: $\quad$ Results of the analyses of groundwater (GW and SP) and surface water (SW) samples collected at Piracicaba (PIR), Rio Claro (RCL) and Passos (PAS) municipalities.

\begin{tabular}{|c|c|c|c|c|c|c|c|c|c|}
\hline Parameter & Unit & GW1 & GW2 & GW3 & GW4 & SP1 & GW & SP2 & SW \\
\hline City & - & PIR & PIR & PIR & PIR & PIR & RCL & PAS & PAS \\
\hline Site & - & $\mathrm{SH}^{\mathrm{a}}$ & $\mathrm{SH}^{\mathrm{a}}$ & $\mathrm{SH}^{\mathrm{a}}$ & $\mathrm{SH}^{\mathrm{a}}$ & Sesi & Church & & \\
\hline WTD $^{b}$ & $\mathrm{~m}$ & 1.5 & 3.0 & 2.7 & 4.5 & & & & \\
\hline $\mathrm{pH}$ & - & 7.0 & 7.0 & 7.0 & 7.5 & 8.1 & 5.9 & 5.9 & 5.9 \\
\hline Temp. & ${ }^{\circ} \mathrm{C}$ & 22.1 & 23.4 & 23.7 & 25.7 & & & & \\
\hline Color & Pt-Co & & & & & & & 0 & 1.0 \\
\hline Coliforms & & & & & & & & Absent & Absent \\
\hline$\sigma^{c}$ & $\mu \mathrm{S} / \mathrm{cm}$ & 305 & 1130 & 750 & 490 & 2000 & 150 & 130 & 120 \\
\hline $\mathrm{OD}^{\mathrm{d}}$ & $\mathrm{mg} / \mathrm{L}$ & 0.5 & 1.4 & 0.6 & 0.5 & & & & \\
\hline $\mathrm{TDS}^{\mathrm{e}}$ & $\mathrm{mg} / \mathrm{L}$ & & & & & 870 & 87 & & \\
\hline $\mathrm{HCO}_{3}^{-}$ & $\mathrm{mg} / \mathrm{L}$ & & & & & 8 & 4 & 12 & 4 \\
\hline $\mathrm{Na}^{+}$ & $\mathrm{mg} / \mathrm{L}$ & & & & & & & 2.3 & 1.7 \\
\hline $\mathrm{K}^{+}$ & $\mathrm{mg} / \mathrm{L}$ & & & & & 0.58 & & 1.0 & 1.0 \\
\hline $\mathrm{Ca}^{2+}$ & $\mathrm{mg} / \mathrm{L}$ & & & & & 1.57 & & 0.17 & 0.43 \\
\hline $\mathrm{Mg}^{2+}$ & $\mathrm{mg} / \mathrm{L}$ & & & & & 0.10 & & 0.69 & 0.53 \\
\hline $\mathrm{SO}_{4}{ }^{2-}$ & $\mathrm{mg} / \mathrm{L}$ & & & & & 276 & $<1.0$ & 1.0 & $<1.0$ \\
\hline $\mathrm{NO}_{3}^{-}$ & $\mathrm{mg} / \mathrm{L}$ & & & & & $<0.4$ & 36.1 & & 0.1 \\
\hline $\mathrm{NO}_{2}^{-}$ & $\mathrm{mg} / \mathrm{L}$ & & & & & 0.016 & 0.013 & & 0.013 \\
\hline $\mathrm{NH}_{4}^{+}$ & $\mathrm{mg} / \mathrm{L}$ & & & & & $<0.01$ & $<0.01$ & & \\
\hline $\mathrm{PO}_{4}{ }^{3-}$ & $\mathrm{mg} / \mathrm{L}$ & & & & & 0.03 & & & \\
\hline $\mathrm{Cl}^{-}$ & $\mathrm{mg} / \mathrm{L}$ & & & & & & 2.6 & 12.5 & 11.0 \\
\hline $\mathrm{F}^{-}$ & $\mathrm{mg} / \mathrm{L}$ & & & & & & & & 2.2 \\
\hline $\mathrm{Ba}^{2+}$ & $\mathrm{mg} / \mathrm{L}$ & & & & & & $<1.0$ & & \\
\hline $\mathrm{Fe}$ & $\mathrm{mg} / \mathrm{L}$ & & & & & & & $<0.05$ & 0.05 \\
\hline $\mathrm{Cr}^{6+}$ & $\mathrm{mg} / \mathrm{L}$ & & & & & & $<0.01$ & & \\
\hline $\mathrm{OM}^{\mathrm{f}}$ & $\mathrm{mg} / \mathrm{L}$ & & & & & $<1.0$ & & & \\
\hline $\mathrm{BOD}^{\mathrm{g}}$ & $\mathrm{mg} / \mathrm{L}$ & & & & & 1.0 & & & \\
\hline
\end{tabular}

\section{Hydrochemical analyses and water quality}

The results obtained for the analyzed samples are reported in Tables 1-5 and compared with guideline values established by three different legislations: Rule No. 8468 established in $8^{\text {th }}$ September 1976 by São Paulo State for the prevention and pollution control of the environment; Rule No. 12486 (NTA60) established in $20^{\text {th }}$ October 1978 by São Paulo State for defining the potable water standards; Rule No. 518 established in $25^{\text {th }}$ March 2004 by the Brazilian Health Ministry for defining the potable water standards.

The values given in Tables 1-4 did not exceed the maximum established by the referred legislations for practically all analyzed parameters, except in some cases now considered. The presence of FOG as a potential pollutant of groundwater resources was identified at Araçatuba city (monitoring wells Nos. 4 and 7) and Penápolis city (monitoring well No. 1) where the limiting value (0.1 $\mathrm{g} / \mathrm{L}$ ) was exceeded. These results indicate that the anthropogenic activities taking 
place at the gas station in Araçatuba city and at the fields irrigated with vinasse for sugarcane crop in Penápolis city are already contaminating the underground resources. In the case of Penápolis city, the value found in groundwater $(3 \mathrm{~g} / \mathrm{L})$ is approximately the same of that for vinasse itself $(4 \mathrm{~g} / \mathrm{L})$, denoting its high infiltration capacity and ability to reach the groundwater table that is not much deep as illustrates the values between 1.5 and $4.5 \mathrm{~m}$ in Table 4 .

The presence of $\mathrm{N}$-compounds as pollutants of groundwater resources was identified at the monitoring wells Nos. 2, 4 and 5 (Araçatuba city), where the nitrate and ammonium contents greatly exceed the limiting values, respectively, $10 \mathrm{mg} / \mathrm{L}$ and $0.5 \mathrm{mg} / \mathrm{L}$ (or $0.08 \mathrm{mg} / \mathrm{L}$ ). Local anthropogenic influences due to non-appropriate release of domestic/industrial wastes may be responsible by the contamination of the shallow aquifer studied. This is reinforced by the more elevated $\mathrm{Cl}^{-}$concentration verified at monitoring well No. 2 and supported by the significant statistical correlation between nitrate and chloride that was obtained by [15] in another aquifer system at São Paulo State. In some cases, this diffuse nitrate pollution may reach deeper aquifer systems exploited by tubular wells whose waters are used for human consumption, as illustrates the value of 36 $\mathrm{mg} / \mathrm{L}$ reported in Table 4 for the groundwater sample collected in an area belonging to a Catholic church located at Rio Claro city.

The N-compounds as groundwater pollutants was also identified at all monitoring wells (for ammonium) and monitoring well No. 3 (for nitrate) in Penápolis city, as well for practically all monitoring wells in José Bonifácio city (Table 3), because the limiting values were again exceeded. However, differently from Araçatuba city, the reason for the groundwater contamination in these localities may be attributed to the field irrigation with vinasse for sugarcane crop, because it has high levels of potassium, calcium and organic matter in its chemical composition as well as moderate amounts of nitrogen and phosphorus $[16,17]$. Such anthropogenic action also is evidenced by the high $\mathrm{K}$ content between 8.3 and $19.7 \mathrm{mg} / \mathrm{L}$ that was found at the monitoring wells Nos. 1-4 in José Bonifácio city (Table 3), as this element is rarely transferred to the liquid phase due to water-soil/rock interactions (see, for instance, the values from 0.04 to $5.3 \mathrm{mg} / \mathrm{L}$ reported by [18] for extremely variable hydrochemical conditions occurring in Guarani aquifer). Additionally, the more acid $\mathrm{pH}$ values from 4.2 to 4.8 at the monitoring wells in José Bonifácio city suggest that the pollution is pronounced as they agree with the $\mathrm{pH}$ between 4 and 5 [16] for the vinasse compounds, confirming they are highly corrosive hazardous substances.

Water-rock interactions also contribute significantly to geogenic input of elements into the liquid phase. Consequently, in many occasions, the chemical composition of groundwater discharging at springs may be equivalent to that of rainwater or surface waters draining terrains exhibiting similar lithology. The chemical analyses of the water samples collected at Passos city area illustrate this aspect (Table 4). The spring water (SP2) has been utilized for human consumption and its composition attend the guideline values defined by the pertinent legislation for the parameters analyzed. However, in other circumstances, this may not occur like verified for the spring water collected at Piracicaba (SP1 in Table 4), as its sulfate content is high $(276 \mathrm{mg} / \mathrm{L})$ and above 
the limiting value corresponding to $250 \mathrm{mg} / \mathrm{L}$ for potable water. The leaching of mineral constituents in sediments from Tubarão Group at the Paraná sedimentary basin is the most probable mechanism responsible by the sulfate enrichment in the waters of SP1 like pointed out by [19] at Águas de São Pedro city located nearby.

Table 5: Results of the analyses of gross alpha and beta activity concentration for water samples collected at Araraquara/ Jaboticabal municipalities and nearby.

\begin{tabular}{ccc|ccc}
\hline Sample & $\begin{array}{c}\text { Gross } \\
\text { alpha } \\
(\mathrm{mBq} / \mathrm{L})\end{array}$ & $\begin{array}{c}\text { Gross } \\
\text { beta } \\
(\mathrm{mBq} / \mathrm{L})\end{array}$ & Sample & $\begin{array}{c}\text { Gross } \\
\text { alpha } \\
(\mathrm{mBq} / \mathrm{L})\end{array}$ & $\begin{array}{c}\text { Gross } \\
\text { beta } \\
(\mathrm{mBq} / \mathrm{L})\end{array}$ \\
\hline COAB1 & 2.9 & 67.2 & Gariroba & 1.8 & $<30.0$ \\
COAB3 & 2.4 & 81.8 & GarirobaG & 3.0 & 58.5 \\
COABJ & $<1.0$ & 30.8 & J.Ipê & 1.9 & 51.1 \\
Well 2518 & $<1.0$ & 60.8 & LFRibeiro & 3.5 & 63.1 \\
Estiva & 1.5 & 69.3 & MLCBatista & $<1.0$ & 36.1 \\
RA1 & $<1.0$ & 44.7 & Itamaraca & $<1.0$ & 59.3 \\
RA2 & $<1.0$ & $<30.0$ & ERodrigues & 4.1 & 47.5 \\
Rico & $<1.0$ & 68.0 & S.Antonio & $<1.0$ & 36.7 \\
Novo & & & & & $<1.0$ \\
V.Negri1 & $<1.0$ & 34.6 & Luzitânia & $<1.0$ \\
V.Negri2 & $<1.0$ & $<30.0$ & Vale Sol & $<1.0$ & $<30.0$ \\
Well C & 7.1 & 47.8 & Jurupema & $<1.0$ & $<30.0$ \\
\hline
\end{tabular}

\section{Radiological aspects of the drinking water quality}

Potential health hazards from natural radionuclides in consuming water have been considered worldwide, with many countries adopting the guideline activity concentration for drinking water quality recommended by [20]. In general, the recommendations apply to routine operational conditions of water supply systems, despite special attention must be given when ground waters are utilized for public water supplies. Several national standards for limiting radiation exposure establish maximum permissible radionuclides concentration in drinking water. The radiological criteria for drinking water quality in Brazil are often related to the Rule No. 518 (25 March 2004) of the Health Ministry, which defines that the identification of the dissolved radionuclides and the measurement of their activity concentrations in the samples should be performed only when the values found in them are greater than $0.1 \mathrm{~Bq} / \mathrm{L}$ for the gross alpha and $1 \mathrm{~Bq} / \mathrm{L}$ for the gross beta activity concentration.

The combined gamma-alpha spectrometric technique that has been developed proved to be useful and reliable to supply data on gross beta and gross alpha radioactivity in water, as shown in Table 5. The results reflect the activity concentration of all radionuclides present in the water sample that remain in a residual solution after evaporation (gross beta) and in its final dry residue (gross 
alpha) deposited into an aluminum disk. The adopted experimental approach permitted estimate critical levels of detection corresponding to $0.03 \mathrm{~Bq} / \mathrm{L}$ and $0.001 \mathrm{~Bq} / \mathrm{L}$ for gross beta and gross alpha radioactivity in waters, respectively. They are much lower than the guideline values established in Brazil, indicating that the techniques are highly satisfactory for application in studies focusing the drinking water quality. Most of the gross alpha activity data reported in Table 5 are below the critical level of detection and all values obtained for gross alpha and beta activities indicate that there is no need for the identification of specific radionuclides and measurement of their activity concentrations in the waters analyzed.

If compared with other similar methods, the method developed is advantageous relatively to those using chromatographic resin and a combination of several reagents and extractants, as the sample preparation is very simple, without the need of any chemicals. Therefore, the technique is environmentally clean, allowing inclusive the recovery of the aluminum disks utilized by their simple washing with water. The instrumentation is also not costly and there is no need for performing additional analyses of $\mathrm{K}$ in order to subtract the ${ }^{40} \mathrm{~K}$ contribution to beta activity. These advantages assure that the method is appropriate for evaluating the drinking water quality as an aid to the management of routine operational conditions of water supply systems. This is a very important task to be considered by a great number of municipalities located at the Paraná sedimentary basin, Brazil, as groundwater has been extensively used and natural radionuclides have been characterized in several rock matrices composing the aquifers strata.

\section{Acknowledgement}

CNPq (National Council for Scientific and Technologic Development) in Brazil is thanked for financial support of this investigation.

\section{References}

[1] Cana, açúcar e álcool: tendência de estabilidade; John Deere, Online. www.deere.com/pt_BR/ag/veja_mais/info_mercado/sugar_cane.html

[2] García, A., Efecto de la concentración de electrolitos en el agua de riego, sobre la recuperación de suelos sódicos. Uso de vinazas. Suelos Ecuatoriales, 24, pp. 80-83, 1994.

[3] Glória, N.A. da, Utilização Agrícola da Vinhaça. Brasil Açucareiro, 86, pp. $11-17,1975$.

[4] COPERSUCAR, Aplicação de vinhaça à soqueira da cana de açúcar em tres anos consecutivos. Boletim Técnico Copersucar, 12, pp. 2-5, 1980.

[5] COPERSUCAR, Efeitos da aplicação da vinhaça como fertilizante em cana de açúcar. Boletim Técnico Copersucar, 7, pp. 9-14, 1986.

[6] Frota paulista cresce quatro vezes em relação à população; Luís Perez, Online. www2.uol.com.br/interpressmotor/noticias/item16664.shl 
[7] HACH, Water Analysis Handbook, $2^{\text {nd }}$ edn., Hach Company: Loveland, 1992.

[8] APHA (American Public Health Association), Standard methods for the examination of water and wastewater. $17^{\text {th }}$ edn, Washington, 1989.

[9] Currie, L.A., Limits for qualitative and quantitative determination. Anal. Chem., 40, pp. 586-593, 1968.

[10] Lederer, C.M., Hollander, J.M. \& Perlman, I., Table of isotopes, $6^{\text {th }}$ edn., Wiley: New York, 1967.

[11] Silva, R.B.G., Estudo hidroquímico e isotópico das águas subterrâneas do aqüífero Botucatu no Estado de São Paulo, Ph.D. Thesis, USP-São Paulo University: São Paulo, 1983.

[12] Almeida, F.F.M. \& Melo, M.S., A bacia do Paraná e o vulcanismo Mesozóico. Mapa geológico do estado de São Paulo, ed. IPT (Instituto de Pesquisas Tecnológicas do Estado de São Paulo), Promocet: São Paulo, v. 1, pp. 46-81, 1981.

[13] Valeriano, C.M. \& Simões, L.S.A., Geochemistry of Proterozoic mafic rocks from the Passos nappe (Minas Gerais, Brazil): tectonic implications to the evolution of the southern Brasilia belt. Revista Brasileira de Geociências, 27, pp. 99-110, 1997.

[14] Araújo, L.M., Franca, A.B. \& Potter, P.E., Hydrogeology of the Mercosul aquifer system in the Paraná and Chaco-Parana Basins, South America, and comparison with the Navajo-Nugget aquifer system, USA. Hydrogeology Journal, 7, pp. 317-336, 1999.

[15] Tonetto, É.M. \& Bonotto, D.M., Hydrochemical relationships in groundwater from central São Paulo State, Brazil. Environmental Geology, 47, pp. 942-955, 2005.

[16] Cortez, L.A.B. \& Brossard Pérez, L.E., Experiences on vinasse disposal. Brazilian Journal of Chemical Engineering, 14 (1), pp. 1-14, 1997.

[17] Gómez, J. \& Rodríguez, O., Effects of vinasse on sugarcane (Saccharum officinarum) productivity. Rev. Fac. Agron., 17, pp. 318-326, 2000.

[18] Bonotto, D.M., Hydro(radio)chemical relationships in the giant Guarani aquifer, Brazil. Journal of Hydrology, 323, pp. 353-386, 2006.

[19] Bonotto, D.M., Dissolved radioelements in (oil) water wells in Paraná basin, Brazil. Water Rock Interaction, ed. R. Cidu, Balkema: Lisse, v. 2, pp. 1485-1488, 2001.

[20] Guidelines for drinking water quality: radiological aspects; WHO (World Health Organization), Online. www.who.int/water_sanitation_health/dwq/ gdwq3/en/ 